\title{
THE PRIVILEGE OF FORCIBLY EJECTING AN AMUSEMENT PATRON *
}

\author{
Alfred F. Conard $\dagger$
}

An amusement proprietor may, in the midst of an entertainment, order a paying patron to leave, and eject him with force if he refuses. Notwithstanding a minority opinion to the contrary, this is text book law. It is also encyclopedia law ${ }^{2}$ and law school law. ${ }^{3}$ Is it law in action?

\section{The Doctrine Questioned}

There are reasons for suspecting that the supposed rule is not actually applied to current cases. Common sense asks what theater proprietor is going to toss out his paying patrons. It is conceivable, to be sure, that he may put out those who violate the regulations of his theater by being Negroes, ${ }^{4}$ or by creating disturbances, or by

* This article is one of a series submitted in satisfaction of the requirements of Columbia University School of Law, for the degree of Doctor of the Science of Law. Other articles of the series are The Requirement of a Sealed Instrument for Conveying Easements (1940) 26 IowA I. REv. 4I; Easements, Licenses and the Statutes of Frands (194I) 5 TEmp. L. Q. 222; Words Which Will Create an Easement (I94I) 6 Mo. L. REv. 245; Easement Novelties (1942) 30 CALIF. L. REv. I25; Unwritten Agreements for the Use of Land, to be published in the Rocky MountaIn LAw REview; and An Analysis of Licenses in Land, to be published in the ColUMBIA IAW REviEw.

$\dagger$ A. B., 1932, Grinnell College; LL. B., 1936, University of Pennsylvania ; LL. M., 1939, Columbia University; member of the Philadeiphia Bar; member of the Legal Staff, Office of Price Administration.

I. 3 TIFFany, Reat Property (3d ed. 1939) 409, n. 45. See also Burdick, Reai PROPERTY (I9I4) 405; WaLSh, PROPERTY (2d ed. I927) 70I. But the contrary rule is stated in TIFFANY, REAL Property (Zollman's abr. ed. I940) 525.

2. 62 C. J. (I933) 86I; 26 R. C. L. (1920) 704, stating that "the only remedy . . is an action for breach of the contract." The statement on the following page that "one holding a ticket of admission ... . is entitled to a seat" is consistent if understood to refer to rights enforceable by an action for breach of contract.

3. Leading casebooks on Property Law, though generally printing decisions illustrative of the contrary view, indicate the weight of authority to be as herein stated. Thus, BIgelow AND MADDEN, CASES ON RJGHTS IN LAND (2d ed. I934) contains Wood v. Leadbitter, I3 M. \& W. 838, r53 Eng. Rep. R. 35I (Ex. I845) (accord); Hurst v. Picture Theatres, [I9I5] I K B. I (contra); Capital Theatre Co. v. Compton, $246 \mathrm{Ky}$. I30, 54 S. W. (2d) 620 (I932) (accord); and notes pro and con. RUNDELI, CASES ON RIGHTS IN LAND (I94I) sets forth Taylor v. Waters, 7 Taunt. 374, 129 Eng. Rep. R. I50 (C. P. I8I6) (contra) ; Wood v. Leadbitter, supra (accord); Cowell v. The Rosehill Racecourse Co., 56 C.' L. R. 605 (Australia, I937) (accord); Marrone v. Washington Jockey Club, 227 U. S. 633 (rgI3) (accord); and notes referring to Hurst v. Picture Theatres, supra (contra) and to the dissenting opinion in the Cowell case, supra. WARREN, CASES ON PROPERTY (2d ed. 1938) presents Wood v. Leadbitter, supra (accord) ; Hurst v. Picture Theatres, supra (contra); and adds a note favoring the former.

Iaw Review notes favoring the dogma are in (1929) 42 HARv. L. REv. 834; (1914) 27 HARV. L. REv. 495; (I9OI) I4 HARV. L. REV. 455; (I937) 53 L. Q. REv. 3I8; (I9I5) 31 L. Q. REv. 217; (I94I) 40 MIICE. L. REV. 324. Notes recognizing but not wholly favoring the dogma are in (rgr5) 63 U. of PA. L. REv. 223; (rgr4) I4 CoL. L. REV. 608; (I9I5) 3I L. Q. REV. 9; (I9I5) I3 MICH. L. REV. 40I; (I938) 5 U. OF CEI. L.
REV. 30I.

4aw" Such a regulation would be invalid in a jurisdiction having a "Civil Rights 
sitting in the wrong seats. In such instances, he is merely expelling one whose presence is not in accordance with the contract of admittance, but in violation of it; and he should not be liable even to return the price of admission. It is also conceivable that ushers will make mistakes, reasonable and unreasonable; as to these it would be necessary only to recognize reasonable mistake, and perhaps good faith, as grounds of defense. But the doctrine goes further; it permits the proprietor to act "for a bad reason or no reason at all." 5 Common sense asks whether proprietors actually put out customers in violation of contract, and without even an honest belief of facts which would constitute good cause.

A second reason for doubting the genuineness of the doctrine inheres in the classic argument which is invoked to support it. The customer has no right against being expelled, it is explained, because that would be a right in land, which can only be given by deed. ${ }^{6}$ The customer has no deed. Evidently the customer would have a right if he had a deed! Common sense steps in again to say that this is mere verbiage. No one ever did, nor ever will, have a deed to a theaten seat; to say that one who has no deed has no right is a misleading way of saying no one has a right. Professor Summers of Illinois used to dramatize this aspect of the problem by asking his students whether you need a deed to see a movie.

A third reason for doubting the actuality of the rule is the shock which it gives to many people's sense of justice. I cannot escape the feeling that an amusement patron who is put out of his seat has been abused in the same sense that a citizen who is driven off the street has been abused, and that the same remedies should be available to him. Evidently some judges feel very similarly. The first cases held for the patron in England, ${ }^{7}$ New York, ${ }^{8}$ Quebec, ${ }^{9}$ Pennsylvania ${ }^{10}$ and Washington. ${ }^{11}$ Most of these decisions gave way to the logic of the argument that the plaintiff should show a deed for his right, or at least an intention to acquire a right "in rem". ${ }^{12}$ But the English courts

5. (I9I5) I3 MICH. L. REv. 40I, 403. See also Gorman v. United Theatres, I77 So. 463 (La. Ct. App. I937).

6. Marrone v. Washington Jockey Club, 227 U. S. 633 (19r3) ; Wood v. Leadbitter, I3 M. \& W. 838, I53 Eng. Rep. R. 35I (Ex. I845). In the former case Mr. Justice Holmes suggested the additional reason that the parties do not ordinarily intend to create a right in rem.

7. Taylor v. Waters, 7 Taunt. 374, 129 Eng. Rep. R. I50 (C. P. 1816).

8. Magoverning v. Staples, 7 Lans. I45 (N. Y. Sup. Ct. I873); MacGowan v. Duff, I4 Daly 315, I2 N. Y. St. Rep. 680 (N. Y. C. P. I887); Smith v. Leo, 92 Hun $242,36 \mathrm{~N}$. Y. Supp. 949 (N. Y. Sup. Ct. I895).

9. Sparrow v. Johnson, 8 Quebec Official L. Rep. 379 (Q. B. 1899).

10. Drew v. Peer, 93 Pa. 234 (r880).

II. Davis v. Tacoma Ry. \& Power Co., 35 Wash. 203, 77 Pac. 209 (I904).

12. Horney v. Nixon, $2 \mathrm{I}_{3} \mathrm{~Pa} .20$, 6r At1. I088 (I905); Finnesey v. Seattle Baseball Club, I22 Wash. 276, 210 Pac. 679 (I922); Wood v. Leadbitter, I3 M. \& W. 838, I53 Eng. Rep. R. 35 I (Ex. I845). 
later reverted to their original opinion, ${ }^{13}$ and at least two American courts have in recent years shown a leaning toward the patron's side. ${ }^{14}$ Mr. Justice Herbert Vere Evatt of the Australian Supreme Court, whose liberal views and keen observations have made him known to American readers, has dissented in favor of the patron. ${ }^{15}$ Two American writers on rights in land and various law review editors have expressed their doubts about the prevailing dogma. ${ }^{16}$ Such differences of opinion about the equities in a factual situation may rest on a misconception in some quarter of what the facts are.

One more suspicious circumstance about the rule is the astuteness with which courts find means of awarding damages in spite of it. In Planchard v. Klaw \& Erlanger New Orleans Theater $\mathrm{Co}_{0}{ }^{17}$ an usher who thought the plaintiff had opened a window said, "So it was you, you smart Aleck; I will have you put out; and I will slap your face," and had the plaintiff led out by a police officer. The police officer said, "If you do not behave, I will put you out," to which the plaintiff replied, "You are not big enough." 18 Without casting any doubt on the rule that a ticket holder's license is revocable, the court allowed recovery of $\$ 500$ (reduced from a verdict of $\$ 2000$ ) for insult and maltreatment. Similar results have followed "incivility" in at least four other states where the doctrine is not challenged, ${ }^{19}$ as well as in two states where the doctrine is doubted but not yet rejected. ${ }^{20}$ Here is either a new tort of insult, ${ }^{21}$ or a practical evasion of the rule that an amusement patron's license is revocable. The rule may also be

13. Hurst v. Picture Theatres, [I9I5] I K. B. I ; accord, Barnswell v. National Amusement Co., 21 Brit. Col. 435, 23 D. L. R. 6I5 (Brit. Col. App. 19I5).

14. Bouknight v. Lester, II9 S. C. 466, II2 S. E. 274 (I92I); Metts v. Charleston Theater, r05 S. C. 19, 89 S. E. 389 (I916); Kelly v. Dent Theaters, 21 S. W. (2d) 592 (Tex. Civ. App. I929), (1930) 8 TEx. L. REv. 60T.

I5. Evatt, J., dissenting, in Cowell v. Rosehill Racecourse, 56 C. L. R. 605, 640 (Australia, I937), 53 L. Q. REv. 3I8. American publications of Mr. Justice Evatt include Judges and the Teachers of Public Lawe (1940) 53 Harv. I. REv. Ir45; Control of Labor Relations in the Commonwealth of Australia (I939) 6 U. OF CHI. L. REv. 529; Some Legal Aspects of Industrial Arbitration in the Commonwealth of Australia (I939) 3 ARB. J. 365 . Since this article was written, Mr. Justice Evatt has broken into the head lines as Minister of External Affairs.

I6. Charles E. Clark, Licenses in Real Property Law (I92I) 2r CoL. L. REv. 757, 778-79, reprinted in REAL CovENANTS AND OTHER INTERESTS WHICE "RUN WITH LAND" (I929) 8, 43-44; Harno, The Revocability of Licenses as Applied to Property in Land (I9I9) 7 KY. L. J. I; (I9I5) 63 U. of PA. L. REv. 223; (IgI4) I4 CoL. L. REv. 608; (19I5) 3I L. Q. REV. 9; (I9I5) I3 MICH. L. REV. 40I;'(I938) 5 U. OF CHI. L. REv. 30I.

I7. I66 La. 235, II7 So. I32 (I928).

I8. Id. at 238,239 , iI $\mathrm{S}$. at 133 .

I9. Weber-Stair Co. v. Fisher, II9 S. W. I95 (Ky. I909) ; Saenger Theatres Corp. v. Herndon, I78 So. 86 (Miss. I938); Ayres v. Middleton Theater Co., 210 S. W. grr (Mo. App. rgrg); Boswell v. Barnum \& Bailey, 135 Tenn. 35, 185 S. W. 692 (I9I6).

20. See cases cited note I4 supra.

2I. This is the view of Professor Prosser, who regards these cases as illustrations of tort liability for causing "mental disturbance." PROSSER, TORTS (I94I) 59-60. The Restatement announces liability for insult only on the part of common carriers, with a 
evaded, while lip service is paid to it, in at least three other ways. One may say that damages for breach of the contract are not confined to the price, but include humiliation; ${ }^{22}$ or that, though the license be revocable, no force may be used in expelling the patron; ${ }^{23}$ or that, though the license be revocable, it is not revocable without reasonable cause. ${ }^{24}$

\section{Factual Situations Disclosed by the Cases}

The suggestion that this respected dogma is not actually used in deciding cases may be regarded by some readers as an impertinence. Readers of this mind will say that if the rule were not "law in action" it would never have become "law in books." Under the common law system, books record the actual decisions of actual controversies. The judge decides nothing that is not presented by the facts of the case; if his words exceed the warrant of his facts, they are disregarded as obiter dicta.

For such a reader, one can only appeal to the cases themselves. In two annotations of the American Lawyer's Reports, a total of twenty-one cases are cited in support of the general rule. None of these cases discloses a set of facts requiring the statement of the rule in its usual form. In four of them, the plaintiff was notified before he obtained a ticket that he would not be admitted, so that he never obtained any valid agreement of admittance; if he bought a ticket, it was with knowledge that its sale to him was unauthorized. ${ }^{25}$ In three of these cases, the plaintiff was stopped at the door without reaching a seat. ${ }^{26}$

caveat as to other public utilities, and amusement proprietors. REstatearenr, ToRTs (1934) $\$ 48$.

22. Aaron v. Ward, 203 N. Y. 35I, 96 N. E. 736 (IgII). This theory is favored by Clark, loc. cit. supra note I6. But see Buenzle v. Newport Amusement Ass'n, 29 R. I. 23,68 At1. 721 (I908).

23. Restatmanent, Property (Servitudes Div., Tent. Draft No. 12, r939) §66, comment $b$; Note (I94I) 40 MiCH. L. REV. 324, 326 .

24. Cummins v. St. Louis Amusement Co., I47 S. W. (2d) I90 (Mo. App. I94I). This formula obviously deprives "revocable" of most of its ordinary meaning, as pointed out in a comment on this case (I94I) $40 \mathrm{MrCH}$. L. REV. 324, 325-26.

25. People ex rel. Burnham v. Flynn, I89 N. Y. I80, 82 N. E. I69 (Ig07) (petitioner in habeas corpus had been arrested for conspiracy to exclude a critic from theaters); Woollcott v. Shubert, 2I7 N. Y. 2I2, III N. E. 829 (IgI6) (proprietor.refused to admit unfriendly critic); Miller v. Pittsburgh Athletic Ass'n, $9 \mathrm{I}$ Pa. Super. 24 I (I927) (tickets being oversubscribed, proprietor refused to sell to plaintiff); Finnesey v. Seattle Baseball Club, I22 Wash. 276, 210 Pac. 679 (I922) (fan had received official notice of exclusion because of bribing and treating players; nevertheless he obtained a seat, and was expelled). Accord, Pearce v. Spalding, I2 Mo. App. I4I (I882) (proprietor refused to sell plaintiff seats of his selection); People on complaint of Zvirin v. Roxy Theatre, 8 N. Y. S. (2d) 92 (N. Y. City Magistrate's Ct. r938) (refusal to sell seats at advertised price); Grannan v. Westchester Racing Ass'n, 153 N. Y. 449,47 N. E. 896 (I897) (plaintiff had been "ruled off the turf" for bribing a jockey).

26. In People v. Flynn, I89 N. Y. I80, I85, 82 N. E. I69, I7I (I907), the question was stated by the court as "whether the proprietor . . has the right to decide who shall be admitted. . . ." (Italics supplied.) In Woollcott v. Shubert, 2I7 N. Y. 212, 216, 
A group of seven cases deals with patrons who were admittedly violating the regulations which the proprietor had established. Three of these patrons were Negroes; ${ }^{27}$ a fourth was disqualified by a regulation against service men in uniform; ${ }^{28}$ others had tickets which were invalid for the night when used, ${ }^{28}$ or for the seats the patron was occupying, ${ }^{30}$ or because of having been resold in violation of their terms. ${ }^{31}$

In four other cases the proprietors evidently would not have sold tickets to the patrons, had they known with whom they were dealing, and the patrons probably knew it. But these facts were not litigated, because the judges held to the theory that the reasons for expulsion are immaterial. I am not, of course, contending that the cases are not authority for that theory. I am discussing the factual situations from which expulsion cases arise. From this point of view, it seems fair to observe that plaintiff Wood was ejected "in consequence of some alleged malpractices of his on a former occasion, connected with the turf;" 32 that Mr. Marrone was expelled "on the charge of having 'doped' or drugged a horse entered by him for a race a few days before." 33 Neither of these accusations can be viewed as an afterthought for bolstering the defense, as each appears to have been made at the moment of expulsion; the latter accusation was pleaded by the plaintiff himself in setting forth the defendant's alleged conspiracy. Both of these cases, which are the preeminent authorities for the doctrine, concern horse races, where most persons do not occupy fixed

III N. E. 829,830 (I9I6), the case was decided on the ground that the proprietor "has the right to decide who shall be admitted or excluded." (Italics supplied.) Nothing in either opinion referred to ejection. In Finnesey v. Seattle Baseball Club, I22 Wash. 276,279 , 210 Pac. 679, 680, 68I (I922), it was "the contention of appellants that the owners of the ball park ... are bound by the same rules as a common carrier of passengers . . or that our civil rights statute was in some way violated. . . ." After rejecting this contention the court added that a customer may be ejected as well as excluded.

27. McCrea v. Marsh, 78 Mass. 2Ir (I858); Burton v. Scherpf, 83 Mass. 133 (I86r) ; Taylor v. Cohn, 47 Ore. 538, 84 Pac. 388 (1906). Accord, Younger v. Judah, III Mo. 303, I9 S. W. II09 (I892); De La Ysla v. Publix Theatres, 82 Utah 598, 26 P. (2d) 8I8 (I933) (Filipino) ; Loew's Montreal Theatres v. Reynolds, 30 Quebec Official L. Rep. 459 (K. B. rgrg). But cf. (under Civil Rights Law) Baylies v. Curry, I28 Ill. 287, 2I N. E. 595 (I899); Bolden v. Grand Rapids \&c. Corp., 239 Mich. 3I8, 214 N. W. 24I (I927); Cremore v. Huber, I8 App. Div. 23I, 45 N. Y. Supp. 947 (I897); and $c f$. (where no previous regulation existed) Drew v. Peer, 93 Pa. 234 (I880) ; Sparrow v. Johnson, 8 Quebec Official L. Rep. 379 (Q. B. I899).

28. Buenzle v. Newport Amusement Ass'n, 29 R. I. 23, 68 Atl. 721 (Ig08).

29. Luxenberg v. Keith \& Proctor Amusement Co., 64 Misc. 69, II7 N. Y. Supp.

979 (N. Y. Sup. Ct. Ig09). Accord, Bouknight v. Lester, IIg S. C. 466, II2 S. E. 274 (I92I). Cf. Schafer v. Tex Rickard, I32 Misc. 489, 229 N. Y. Supp. 47 I (N. Y. Mun. Ct. 1928) (plaintiff arrived after gates had closed for Dempsey-Sharkey fight).

30. Hyde v. Toronto Theatre, I7 Ont. W. R. 380 (I910). Accord, Powell v. Weber-Stair Co., I25 S. W. 255 (Ky. I9IO).

3I. Purcell v. Daly, ig Abb. N. C. 301 (N. Y. Dist. Ct. r886). See also Collister v. Hayman, 183 N. Y. 250,76 N. E. 20 (1905); Harris v. Jack's Theatre Ticket Service, I39 Misc. III, 246 N. Y. Supp. 396 (I930).

32. Wood v. Leadbitter, I3 M. \& W. 838, is3 Eng. Rep. R. 351 (Ex. I845).

33. Marrone v. Washington Jockey Club, 227 U. S. 633 (1913). 
seats, but move about, and where by common knowledge large numbers of detectives are required to deal with the large numbers of malefactors which are usually present. Somewhat similar is the case of Meisner, who was refused admittance to an amusement park on the ground that he had previously caused disturbances. ${ }^{34}$

The fourth case of the present group is that in which Lee Shubert, theatrical producer, was attending a Newark show of his competitor, Florenz Ziegfeld. ${ }^{35}$ Shubert was in a seat and was not misbehaving; he was ordered to leave, and did so, so far as his pleading reveals, without any force being applied or threatened. This would seem to present a pure case of breach of contract, with no tort under any view of the law, ${ }^{36}$ but it is commonly treated as an application of the usual rule. No reason for ejecting him appears from the record, excepting his name. It is the Shuberts' story that he was expelled because of personal difficulties over a loan. ${ }^{37} \mathrm{Mr}$. Ziegfeld is able to tell no tales. But it is certain that Shubert was then living in New York, where he owned several shows, as well as others on tour. For years before and after the Newark incident there raged a trade war between the "independents" (the Shuberts) and the "syndicate" (Klaw and Erlanger). Ziegfeld was backed by Erlanger. The rivalry extended as widely as the circuits, and it was front page copy. A regular feature of competition in this era was spotting attractive performers of other companies, and making them flattering offers after the show, regardless of Lumley $v$. Gye. ${ }^{38}$ Unless Shubert had travelled to Newark that evening purely to enjoy Ziegfeld's show, it is doubtful that he really thought of himself as a welcome guest. Even in a state where the theater has a duty of public service, its duty is to furnish amusement, not business opportunities. ${ }^{39}$

In four cases it seems likely that the proprietor broke the contract of admittance, not by putting the patron out but by refusing to seat him; the transaction was still in the executory stage. In one case, the seats had been erroneously given to some one else, ${ }^{40}$ in another,

34. Meisner v. Detroit \&c. Ferry Co., I54 Mich. 545, II8 N. W. I4 (I908). defendant.

35. Shubert v. Nixon Co., 83 N. J. L. ror, 83 Atl. 369 (rgra). Ziegreld was a co-

36. The complaint seems to have been framed on the theory that the Civil Rights Laws put the amusement proprietors under a duty to serve all comers, a theory which had been adopted in Greeneberg v. Western Turf Ass'n, I40 Cal. 357, 73 Pac. 1050 (Ig03), and which had some influence upon Aaron v. Ward, 203 N. Y. 35I, 96 N. E. 736 (I9II).

37. From an interview of the writer with William Klein, counsel to the Shuberts.

38. See A.J. Liebling, The Boys from Syracuse (a biography of the Shuberts), NEw YORKER, Nov. 25, 1939, pp. 23-25; Eddie Cantor, Ziegfeld and His Follies, CoLLIERS, Jan. I3, 20, 27, Feb. 3, I0, I7, I934; William Lyon Phelps, The New Theatre (I909) 67 INDEPENDENT 957.

39. Greeneberg v. Western Turf Ass'n, I40 Cal. 357, 73 Pac. Io50 (Ig03).

40. Boswell v. Barnum \& Bailey, I35 Tenn. 35, I85 S. W. 692 (IgI6). 
the manager claimed he had no seats. ${ }^{41}$ It is interesting that in both of these cases the plaintiffs actually recovered substantial damages, on the ground of "incivility" and "rudeness" in the manner of their expulsion. ${ }^{42}$ In a third case the proprietor had sold seats which he had been obliged by municipal officers to eliminate; ${ }^{43}$ in a fourth, all that appears is the fact of exclusion from a seat, after passing the ticket taker. ${ }^{44}$

The two remaining decisions present no relevant fact situation. In passing on the validity of a statute for licensing ticket brokers, one of them repeated the usual dogma that a ticket creates only a revocable license. ${ }^{45}$ In the other, the proprietor was not sued for assault but himself brought suit in trespass against a licensee of the previous owner. ${ }^{46}$

If we turn from the cases decided for the proprietor to those in which the customer obtained judgment, substantial reasons for expulsion are equally apparent. The annotations previously referred to cite eight cases. In two, the patrons were Negroes; but since no regulation was shown to have been established, the expulsion was held arbitrary.47 In another, in which substantial damages were allowed apparently on a contract theory, the patron was admittedly involved in a quarrel with a neighbor over their respective places in line; ${ }^{48}$ apparently the jury decided that the plaintiff had been right in the quarrel. In two cases, one of which established the modern English view, the proprietors mistakenly supposed that the plaintiffs were occupying wrong seats. ${ }^{49}$ In another, the patron was in fact attending on a night to which his ticket did not entitle him, and his right to compensatory damages slipped by unchallenged in a debate about punitive damages. ${ }^{50}$ In the earliest English case, the proprietors who excluded the plaintiff were

4I. Ayres v. Middleton Theater Co., 2ro S. W. 9 II (Mo. App. I9I9).

42. Compare cases cited notes I4, I7, I9, supra.

43. Horney v. Nixon, $213 \mathrm{~Pa}$. 20, 6I Atl. I088 (I905). "A theater ticket is to be regarded as a mere license, for the revocation of which, before the holder has actually been given his seat and has taken it, the only remedy is in assumpsit for breach of contract." Id. at 27, 6r Atl. at Iogo. (Italics supplied.)

44. W. W. V. Co. v. Black, II3 Va. 728, 75 S. E. 82 (19r2).

45. Opinion of the Justices, 247 Mass. 589, I43 N. E. 808 (1924).

46. Coleman v. Foster, I H. \& N. 37, 156 Eng. Rep. R. II08 (Ex. 1856). Notwithstanding the numerous dicta that a ticket holder is a trespasser after revocation of his license, this appears to be the only decision which ever held him liable for trespass; in this case the licensor's sub-lessee refused (at the entrance) to honor a "season ticket."

47. Drew v. Peer, $93 \mathrm{~Pa} .234$ (1880) ; Sparrow v. Johnson, 8 Quebec Official L. Rep. 379 (Q. B. 1899).

48. Aaron v. Ward, 203 N. Y. 35I, 96 N. E. 736 (I9II). Cf. Cummins v. St. Louis Amusement Co., I47 S. W. (2d) 190 (Mo. App. I94I), where the audience broke into commotion during a breakdown of the projector, and an usher mistook the 13 year old plaintiff for a participant.

49. Bouknight v. Lester, IIg S. C. 466, II2 S. E. 274 (I92I) ; Hurst v. Picture Theatres, [IgI5] I K. B. I.

50. MacGowan v. Duff, I4 Daly 315, I2 N. Y. St. Rep. 680 (N. Y. C. P. I8987). 
assignees of earlier proprietors who had sold the plaintiff his twenty'one year subscription to a box. ${ }^{51}$ In only one of the eight cases does no reason for the expulsion appear, and this involves a dancing school from whose dance the plaintiff was ejected. ${ }^{52}$ This recalls the race course and amusement park cases; the plaintiff has no fixed location to which he can claim a right, and because he moves from place to place his mere personality or appearance may make it desirable for the proprietor to remove him.

It is evident that the conception of a proprietor arbitrarily expelling a patron is a legal fiction. Proprietors very rarely expel patrons who are not violating established rules, or suspected of it, despite their legal privilege to do so. On the other hand, proprietors do exclude patrons on a variety of grounds which are not always reasonable.

It further appears that proprietors' legal privileges both of exclusion and of expulsion are limited by a vague ground of liability which consists in exercising the privilege of expulsion with an uncivil tongue. As a result of this doctrine, a proprietor cannot effect an expulsion without becoming vulnerable to a jury finding against him, regardless of whether a privilege to expel is or is not ostensibly recognized.

\section{Factual Situations Disclosed Outside the Cases}

The cases do not show that arbitrary forcible ejections are an existing problem. I have therefore inquired of several lawyers and laymen to see whether experience supplies what the reports do not.

The theater lawyers, naturally enough, denied that any such ejections occur. I gave their general denial the credence to which such pleadings are usually entitled, but one of them supplied some convincing reasons for his statement. He represented a large number of neighborhood cinema theaters in a large city, and observed that his patrons come to the theater for escape from emotional insecurity. Nothing must go on which would break in upon the sense of personal security in the theater. Suspicious characters may be stopped in the lobby, but in the theater proper, no conflicts between management and patron can be tolerated. If a Negro, who would usually be excluded, reaches a seat, he is not ousted from it. Even disorderly patrons are not expelled unless absolutely necessary. Although drunk this week, they may be sober next week. If they prove to be habitual offenders, they can be recognized at the door, and forbidden to enter.

51. Taylor v. Waters, 7 Taunt. 374, I29 Eng. Rep. R. I50 (C. P. I8I6).

52. Smith v. Leo, 92 Hun 242, 36 N. Y. Supp. 949 (Sup. Ct. I895). 
One of the lawyers who furnished this account of proprietors' attitudes was William Klein, who for some thirty years has represented the Shubert brothers' theater empire. It was ridiculous, he asserted, to suggest that a management would order or tolerate arbitrary expulsions. Then I asked him about the case in which Lee Shubert was expelled from a Ziegfeld show in a Newark theater. ${ }^{53}$ This, he said after some thought, was the exception to the rule. Shubert was a bona fide customer, seeking entertainment. Ziegfeld disliked him because of a loan over which they had disagreed. But it was the only exception he had ever heard of. Moreover, no force was used on Shubert-a fact which the reported case confirms. Klein says that the management refused to raise the curtain unless Shubert would leave, which Shubert obligingly did. "I guess any one would under those circumstances," observed Mr. Klein. ${ }^{54}$

Was it just as well, really, that Shubert had failed to recover; and that, if another such instance should occur, no substantial damages should be recovered? Mr. Klein wouldn't say so.

"If a man is put out of a seat as Shubert was," said Mr. Klein, "he has a right to be mad. I think he ought to get all the damages he can."

Other theater lawyers declined to express themselves upon the justice due to an arbitrarily ejected patron. The case doesn't exist, they said. I inferred that they felt some difficulty in saying that such a customer should go without any remedy but a refund.

Theater lawyers are not impartial observers of the scene, but I had reason to believe that they were frank with me. For example, most of the New York lawyers admitted that despite the Civil Rights law ${ }^{55}$ a Negro cannot gain admittance to the orchestra floor of their theaters. One told me that sex perverts who molest female customers are sometimes taken to the alley and beaten up; they are not the type to make a complaint. $^{56}$ They made no secret of the facts, which were confirmed by a national insurance organization, ${ }^{57}$ that liabilities for accidents caused by defective equipment run into significant figures, while liabilities for expulsions and exclusions of all sorts, including Civil Rights cases, are financially insignificant.

Other factors led me to believe that the problem of arbitrary expulsion is practically unknown. Three New York lawyers, in telling

53. Shubert v. Nixon Amusement Co., 83 N. J. L. IoI, 83 Atl. 369 (Igr2).

54. Alexander Woollcott ("the man who came to dinner") has orally avowed he would not leave under such circumstances.

55. N. Y. Cons. Laws (Cahill, 1930) $\S \S 40,4 \mathrm{r}$.

56. This surprising report was not corroborated by any other informant.

57. The National Board of Casualty and Surety Underwriters, New York City, through the courtesy of Mr. E. W. Sawyer. 
me what the law is, repeated the dogma that a customer has only a revocable license, and that his only remedy if expelled is refund of his admission price: When I reminded them of the Court of Appeals decision allowing damages of $\$ 250$ for humiliation caused by breach of contract, none of them had a clear recollection of the case. ${ }^{58}$ It is not important in their practice.

The same fact was impressively demonstrated by my conversation with the attorney for a large group of legitimate theaters. He told me that his organization was fully protected by a "revocable license" clause on the reverse of each ticket.58 I responded that I had seen some of his tickets which did not have it, although it was usually present on the tickets of the cinema theaters. He drew some tickets from his desk, and was startled to find no revocable license clause upon them. The attorney immediately lifted his phone and called his general manager for an explanation. After a few moments' conversation he hung up, and said that they used to print the clause a few years before, but had given it up to save printing expense. He said he would look into it.

If there were to be any complaints of the actual conduct of theater managements, it would evidently have to come from outside the theater. Legal aid lawyers in two cities had never encountered the problem. A lawyer at the American Civil Liberties Union was sure that they had. never had any complaints of persecution by way of ejection from theaters. However, he pointed out that this was not within the scope of A. C. L. U. activities. Like the fifth and fourteenth amendments, it is concerned with the acts of governments, not of individuals.

At the Association for the Advancement of Colored People, there was no lack of complaint about the conduct of theaters. But even here there was no complaint about arbitrary expulsions. The lawyer with whom I talked confirmed the theater lawyers' story that Negroes are stopped at the entrance or not at all. If one obtains a seat, the management thinks it best to leave him there. This very practice was cited to show that Negroes do not really interfere with white persons' enjoyment of a show.

My best witness is Alexander Woollcott. For years he was a theater critic, and carried his own feud with the Shubert brothers to the Court of Appeals of New York. No one will suppose that Woollcott would let a good instance of arbitrary expulsion escape his literary acquisitiveness. But he had never heard of an expulsion, except for

58. Aaron v. Ward, 203 N. X. 35I, 96 N. E. 736 (IgII).

59. How much protection would this give? (I) It is not brought to the actual consciousness of most patrons. (2) It is in the nature of a release for future assaults, and against public policy. But see Clark, Licenses in Real Property Law (I92I) 21 CoL. L. REv. 757, 777, reprinted in REAL COVENANTS AND OTHER INTERESTS WHICH "RUN With LAND"'(1929) 8, 43, 1. 99. 
disorderliness. ${ }^{\circ 0} \mathrm{He}$ himself was never expelled, although he was repeatedly excluded at the entrance, and once sat through a show by virtue of a writ of injunction, surrounded by private detectives and observed by a crew of feature writers. Even the exclusions took place only after he had been amply warned that he would not be admitted. Woollcott persuaded me that I was searching for a missing link.

\section{Function of the Doctrine}

- It might seem logical to conclude that the legal privilege of arbitrary expulsion of customers should be abolished. There are visible tendencies in that direction. ${ }^{61}$ Yet none of the several lawyers, and more numerous laymen whom I have consulted saw any merit in such a change in the law. A typical layman's comment was made by a woman who had no legal training whatever.

"I don't think a customer should get any damages," she said, "because if there weren't something wrong with him he wouldn't be put out." Obviously this answer begs the question by refusing to admit that the plaintiff has been arbitrarily ejected. But it has practical merit if there are no arbitrary ejections.

A similar thought underlies the answers of the lawyers, who usually said that they didn't favor conferring a right to recover damages, because that would raise in every case a jury question of the reasonableness of the expulsion. The jury might find arbitrariness where none existed. ${ }^{62}$ Tacitly or expressly, they admit that an arbitrarily and forcibly ejected patron should get damages. But no threat of damages is necessary to make sure that the theaters will not be arbitrary; potential loss of good will is penalty enough.

These judgments appear upon analysis to have two aspects. One is distrust of the court's ability to determine correctly the good faith or the reasonableness of the defendant and his agents. We state a law which we do not like in order to prevent the giving of judgment by a tribunal which we do not trust. This view of the matter helps explain why Mr. Justice Holmes, usually solicitous of citizens' rights, was so careless of the ejected theater patron. He profoundly distrusted the jury. The rule that a proprietor might eject a patron was probably one of the "rules of law based on less than universal considerations" which "are made absolute and universal in order to limit those over

60 . The expulsion of Shubert by Ziegfeld, above, occurred a few years before Woollcott became a theater critic, and its particular circumstances were unknown to him.

6r. (I) Cases which repudiate the prevailing dogma, cited notes I3, I4, I5, supra; (2) cases allowing damages for uncivil language, cited notes I7, Ig, supra.

62. Prof. Edwin W. Patterson calls this problem "the juridical risk," in The $A p$ portionnent of Business Risks Through Legal Devices (I924) 24 CoL. I. REv. 335, 340 . 
refined speculations that we all deprecate." He observed, as an example of this principle, "It is not thought worth while to let the right to build or maintain a barn depend upon the speculations of a jury as to motives." 63

The other element in the opinion that the law should not be changed is confidence that proprietors will act with decent caution, regardless of legal sanctions. Such confidence, or lack of it, is likely to depend on our social attitude toward proprietors in general. Such social attitudes are said by some to have influenced development of the fellow servant rule, ${ }^{64}$ and of the law of spring guns, ${ }^{65}$ while others vigorously deny any such connection. ${ }^{66}$ It is notable that the spring-gun and fellow servant cases are contemporaneous with the leading ticket cases, and that the latter could be used to throw fuel on the fire which rages over the former. It could be pointed out that the plaintiff who won the first ticket case was an evidently estimable person who had made a twentyone year subscription to an opera box, and who held a silver token to witness his rights, while the proprietors were apparently commercial operators. ${ }^{67}$ But the defendant who won the second case was acting on instructions of Lord Eglintoun, marshal of the races, while the plaintiff was one who had been accused of drugging a horse. ${ }^{68}$ I do not attempt to assess the merits of this interpretation. But I note that Mr. Justice Evatt, who would overrule the second ticket case, ${ }^{69}$ is the same writer who sees evidence of class consciousness in the spring gun and fellow servant cases. ${ }^{70} \mathrm{Mr}$. Chief Justice Latham, who opposed him, warned that the principle of Hurst's case would justify the sitdown strike. ${ }^{71}$

There is another factor in the belief that landowners do not need legal sanctions, which is wholly independent of any particular faith in landowners. ${ }^{72}$ This is the belief that economic pressure coerces the proprietors to be fair more effectively than legal sanctions ever can. Almost all the theater lawyers, and many of the laymen to whom I spoke, shared this opinion. In the case of the exclusion of a critic,

63. Holmes, J., partially concurring, in Leroy Fibre Co. v. Chicago, M. \& St. P. Ry., 232 U. S. 340,353 (I9I4). (Italics supplied.)

64. Priestley v. Fowler, 3 M. \& W. I, I50 Eng. Rep. R. I030 (Ex. I837).

65. Bird v. Holbrook, 4 Bing. 628, I30 Eng. Rep. R. 9II (C. P. I828); Ilott v. Wilkes, 3 B. \& Ald. 304 , I06 Eng. Rep. R. 674 (K B. I820).

66. See Pound, The Economic Interpretation and the Lave of Torts (1940) 53

Harv. L. Rev. 365; Evatt, The Judges and the Teachers of Public Laze (1940) 53 HARV. L. REV. II45, II48-52.

67. Taylor v. Waters, 7 Taunt. 374, I29 Eng. Rep. R. I50 (C. P. I8I6).

68. Wood v. Leadbitter, I3 M. \& W. 838, I53 Eng. Rep. R. 35I (Ex. I845).

69. Cowell v. Rosehill Racecourse, 56 C. L. R. 605, 640 (Australia, I937) (dissenting opinion).

70. Notes 64,65 , supra.

7I. Cowell v. Rosehill Racecourse, 56 C. L. R. 605, 62I (Australia, I937).

72. See Note (I94I) 40 MICH. L. REv. 324, 326. 
the superiority of economic over legal forces has been demonstrated. Let Woollcott tell the story:

"As the first gestures failed to induce the Times to send another reviewer to their shows, they [the Shuberts] tried out the system of barring me from the theater. . . Within ten minutes the Times had excluded all Shubert advertising from its columns and also all allusion to any actor playing in a Shubert theater. Next it instituted in my name an application for permanent injunction. ... There were thus two entirely separate weapons brought to bear.

"In the case of the legal weapon, we lost. . . . There was some faint-hearted talk of agitation for ... a statute but at the time I saw no point in it. If a newspaper is pusillanimous the statute would not do its readers any good. If a newspaper is independent in spirit it needs no such statute. This was demonstrated in my own case because, having won the decision in the courts, the Shuberts were no better off than before. Their plays, their players and their advertising were ignored. Under this treatment they soon came begging for my return and even ate crow in the form of an open letter asking me to return." 73

It is probable that remedies for arbitrary expulsion of individuals are similarly self-operating. This is not to deny that proprietors are ever arbitrary; but their arbitrariness takes forms which are not affected by the existence or non-existence of a privilege of expulsion. Usually they bar an individual at the entrance, rather than disturb a larger audience later. Accordingly Civil Rights laws wisely inhibit exclusion, as well as expulsion, on racial or religious grounds. ${ }^{74}$ Even so, they are often ineffective because jurors accept the manager's explanation that it was on other grounds that the exclusion was made. ${ }^{75}$ Perhaps an effective Civil Rights law must require the amusement enterprise, like a public utility, to serve all comers. The California law has been construed to apply to every applicant who is not disorderly; ${ }^{76}$ the New York law has been recently amended to require admittance of all who are not disorderly, and who present tickets to stage productions. ${ }^{77}$

There is another reason why the privilege of forcible expulsion is not the crux of the problem. The ushers may proceed by ordering a patron to leave, and obtain compliance without employing force at all. The patron with female guests, who is most likely to suffer actual

73. From a letter sent by Woollcott, June $5,1938$.

74. N. Y. Cons. Laws (Cahill, I930) c. 6 , $\$ \$ 40,4 I$; ILL. Rev. STat. (Cahill and Jones, 1933) c. 38 , $\$ \$ 550-555$.

75. According to an attorney representing the Association for the Advancement of Colored People.

76. Greeneberg v. Western Turf Ass'n, I40 Cal. 357, 73 Pac. I050 (I903).

77. N. Y. CoNs. Laws (Cahill, Cum. Supp. I94I) c. 7, § 40-b. 
annoyance and humiliation, commonly complies with this request. ${ }^{78}$ He has suffered the same type of damage as an abused hotel or railway patron but has sustained no assault at all.

I conclude that the proprietor's privilege of arbitrary expulsion serves a somewhat useful purpose, for the strange reason that practically no arbitrary expulsions occur. It protects a proprietor from liability to a patron whom he has expelled with a reasonable, or at least an honest, belief that he constituted a present threat to order in the theater, by giving the jury no chance to find erroneously that the manager was arbitrary. This is not the ground on which the rule has been previously defended as socially useful. For example it has been suggested by Professor Warren that it is useful because the patron should be discouraged from disturbing the theater by offering physical resistance to his ejection. ${ }^{79} \mathrm{He}$ evidently assumes that angry patrons would know what the law is, and would resist an usher only if they could recover damages for his use of force. But it is obvious that patrons don't and won't know the law; I have found even lawyers rather hazy on it. As to the unusual patron, who, like Woollcott, has decided to make a test of his power, he will hardly miss the opportunity of making the usher go to a maximum of trouble in getting rid of him. The suggestion that the rule of law would influence the patron to avoid resistance is one which $I$ have never heard from a practicing lawyer. ${ }^{80}$

The justification which I have proposed for the privilege of expulsion can be objected to only if there are in fact cases of arbitrary forcible expulsion. This is a question of fact, on which my best information is that they do not exist.

If arbitrary ejections actually occur, the problem which presents itself is a very different one. Patrons and proprietors alike agree that such conduct, if it exists, should be discouraged. Proprietors, unlike patrons, are quite susceptible to being affected in their behavior by rules of law, since they constantly retain counsel to advise their procedures. There appears no reason why liability to a damage action would not increase proprietors' care to avoid arbitrary acts.

Various objections which suggest themselves must be disposed of. The suggestion that proprietors do not need to be coerced begs the 'question; we are considering what the law should be if the non-legal sanctions are not working. The suggestion that jury verdicts would fall alike on the just and on the unjust is more serious; but it is equally

78. No actual assault appears in several cases where the plaintiff recovered for incivility. See cases cited in notes I4, I7, I9, stupra.

79. Warren, Cases on Property (2d ed. I938) 925.

80. See Clark, Licenses in Real Property Lare (I92I) 2I Cor. L. Rev. 757, 777, reprinted in REAL Covenants aND OtHeR INTEREsts Which "RUN With LAND" (I929) 8,43 . 
available to condemn the existing rule which makes a proprietor liable for use of excessive force. In both cases, judges should be enabled to exercise a greater control over the jury. It will be suggested further that a proprietor would have no choice, since he is liable to other customers for failure to remove evidently boisterous persons, ${ }^{81}$ and he would now become liable to any whom he removed, erroneously believing him to be boisterous.

This argument is like that made for the proprietor in the early spring gun case; ${ }^{82}$ the proprietor, if liable, would have to choose between losing some produce, or paying damages to injured trespassers. The law decided to present him with this unpleasant alternative. ${ }^{83}$ The difficulty can be mitigated by avoiding the general tort rule, which confers a privilege only if the proprietor's mistake is induced by the subject's own fault, ${ }^{84}$ and conferring the privilege wherever the mistake is one which a reasonable man would have made.

\section{CONCLUSTONS}

Amusement proprietors do not arbitrarily eject their patrons. They do refuse admittance more or less arbitrarily. Occasionally they eject patrons whom they believe to be disorderly or to have violated the rules of admittance. In such cases their belief is honest, but not always reasonable. If a proprietor should eject a patron whom he did not believe to be violating established rules of admittance or of conduct, he would be considered unfair by his fellow-tradesmen as well as by the public.

The law as commonly stated permits the proprietor to eject arbitrarily as well as for cause. But the privilege is illusory, because the jury may find the proprietor liable for use of excessive force or incivility. If the law were restated to forbid arbitrary or unreasonable ejections, the principal effects would be to give the jury an additional opportunity for holding proprietors liable who act reasonably or in good faith, and to impede performance of the proprietor's duty to keep his premises safe for others. Such a restatement would, however, comply more nearly than does the usual dogma with prevailing concepts of justice.

8r. Savannah Theatres Co. v. Brown, 36 Ga. App. 352, 136 S. E. 478 (I927); Daniels v. Firm Amusement Co., I58 Misc. 25I, 285 N. Y. Supp. 557 (Manhattan Mun. Ct. I935) ; Marek, v. Southern Enterprises, I28 Tex. 377, 99 S. W. (2d) 594 (I936).

82. Ilott v. Wilkes, 3 B. \& Ald. 304, 106 Eng. Rep. R. 674 (K. B. I820).

83. Bird v. Holbrook, 4 Bing. 628, I30 Eng. Rep. R. 9 Ir (C. P. I828).

84. Restatement, ToRts (I934) $\$ 78$. 